\title{
SOUTH-MORAVIAN RURAL BORDERLAND
}

\author{
Antonín Vaishar ${ }^{1}$, Milada Št’astná ${ }^{2}$, Pavel Trnka ${ }^{3}$, \\ Petr Dvořák ${ }^{4}$, Jana Zapletalová ${ }^{5}$
}

Received 19 December 2012; Accepted 21 May 2013

\begin{abstract}
The South Moravian rural borderland has been studied as an example of peripheral countryside. It is defined by municipalities the cadastral districts of which border on the state frontiers. The borderland is considerably differentiated in dependence on the natural conditions, historic development, geographical position and subjective circumstances. The period after 1990 experienced a downturn in production sectors, development of the tertiary sector, quite positive demographic evolution with a positive migration balance (with some exceptions), further intensification of nature conservation and landscape protection, increased unemployment rate and lower standard of formal education. The strengths encompass the maintained and, in many cases, strictly protected landscape, suitable settlement structures with large villages, suitable conditions for agricultural activities, development of balneology and important transition position of the central part of the borderland. The weaknesses include, in particular, the distinctly seasonal character of tourism (short summer period), below-average education, poor condition of many local roads and exposedness of the territory to erosion. Opportunities include possibilities of international cooperation, support of non-production agriculture, demand for relevant forms of tourism, support of small and medium sized businesses. Threats are understood as the outflow of young and educated people, devastation of the environment through intensive farming and reduced economic competitive advantages. Strategies may consist in the preference of economic development or in focusing on the improvement of local inhabitants' life quality.
\end{abstract}

Key words: borderland, landscape, rural settlement, economy, strategy, Moravia

Souhrn: Jihomoravské pohraničí bylo studováno jako př́klad periferního venkova. Je definováno souborem obcí, jejichž katastrální území se dotýkají státní hranice. Pohraničí je významně diferencováno v závislosti na přírodních podmínkách,

\footnotetext{
${ }^{1}$ Doc. RNDr. Antonín Vaishar, CSc., Department of Applied and Landscape Ecology, Faculty of Agronomy, Mendel University in Brno, Zemědělská 1, 61300 Brno, Czech Republic, e-mail: antonin.vaishar@mendelu.cz

2 Doc. Ing. Milada Št'astná, PhD., Department of Applied and Landscape Ecology, Faculty of Agronomy, Mendel University in Brno, Zemědělská 1, 61300 Brno, Czech Republic, e-mail: stastna@mendelu.cz

${ }^{3}$ RNDr. Pavel Trnka, CSc. (†), Department of Applied and Landscape Ecology, Faculty of Agronomy, Mendel University in Brno, Zemědělská 1, 61300 Brno, Czech Republic

${ }^{4}$ Mgr. Petr Dvořák, PhD., Department of Environmental Geography, Institute of Geonics, Czech Academy of Sciences Ostrava, Studentská 1768, 70800 Ostrava-Poruba, Czech Republic, e-mail: dvorak@ugn.cas.cz

${ }^{5}$ RNDr. Jana Zapletalová, CSc., Department of Environmental Geography, Institute of Geonics, Czech Academy of Sciences Ostrava, Drobného 28, 60200 Brno, Czech Republic, e-mail: zapletalova@geonika.cz
} 
historickém vývoji a subjektivních okolnostech. Období po roce 1990 Ize charakterizovat propadem výrobního sektoru, rozvojem služeb, pozitivním migračním saldem (s několika výjimkami), zvýšeným dưrazem na ochranu prírody a krajiny, stoupající nezaměstnaností a nízkým standardem formálního vzdělání. Silné stránky spočívají $v$ udržované $a$ v řadě případủ přísně chráněné krajině, vhodné sídelní struktuře s relativně velkými obcemi, vhodných podmínkách pro zemědělské aktivity, rozvoji balneologie a významnou tranzitní polohou centrální části pohraničí. Slabé stránky zahrnují zejména výrazně sezónní charakter cestovního ruchu (pouze krátká letní perioda), podprůměrné vzdělání obyvatel, špatný stav místních komunikací, vystavení území erozi. Příležitostmi jsou možnosti přeshraniční spolupráce, podpora mimoprodukčního zemědělství, poptávka po odpovídajících formách cestovního ruchu, podpora malého a středního podnikání. Ohrožení je chápáno jako nebezpečí dalšího odchodu mladých a vzdělaných lidí, možná devastace životního prostředí intenzivním zemědělstvím a nižší ekonomická konkurenceschopnost. Strategie mohou spočívat $v$ preferování ekonomického rozvoje nebo v zaměření na kvalitu života místní populace.

Klíčová slova: pohraničí, krajina, venkovské osídlení, hospodářství, strategie, Morava

\section{Introduction}

The South Moravia region is located in the southeast of the Czech Republic. In the East it borders on Slovakia, and in the South on Austria. The settlement structure in the region consists of the regional city of Brno, the importance of which goes beyond the regional borders, five middle-sized district towns (20 - 35 thousand inhabitants) and rural municipalities including a number of small towns with nine of them having $5-11$ thousand inhabitants. The respective analysis (Woods, Jones, 2009) concluded that the countryside in the region is diverse and the surroundings of Brno are very different from remote micro-regions. These micro-regions include both the so-called "internal peripheries" (in particular, close to the historic MoravianCzech borders in the West and North), and the borderland. The borderland itself is strongly differentiated, though (Hampl, 2000).

The article below focuses on a more detailed survey of the situation in the borderland. Its main objective is to analyse, in a relatively comprehensive manner, the situation in terms of the development potential, determine the differences between the individual borderland areas and their dependences and comment on further perspectives.

\section{Theory and methodology}

Häkli and Kaplan (2002) show, how the concept of European borderlands has been changed during the last 100 years - from their demarcating character after World War I through curtains dividing different ideological systems to regions of collaboration. Bufon (2007) shows a macro level consisting in international relations and a micro level, which is based on every-day human relations just on the border.

The borderland may be defined in several ways (see, for example, Jeřábek et al., 2004). In previous studies (e.g. Vaishar et al., 2008) we made use of catchment areas administered by relevant local authorities. This definition is logical in terms of the settlement structure but as regards the South Moravian borderland, centres such as Znojmo, Břeclav and Hodonín reach relatively far into the inland. In our case, the historic-sociological identification of the borderland with the area of the post-war ethnical replacement of inhabitants (Chromý, 2000) is not acceptable either, as this definition excludes the Slovak borderland.

However, our paper is focused on rural borderland seen as a periphery. The border aspect is included as a factor of peripherality. There is no common understanding about the concept of rural periphery. Ferrão and Lopes (2004) introduce a four-dimensional concept of rural periphery: as distance, as dependence, as difference and as discourse. An explanation to what 
extent the South Moravian borderland and its individual sections answer to these four dimensions is one of the aims of the empirical part of this paper.

The relation between borderland and periphery is discussed by Bański et al. (2010). The authors point out that borderland is usually situated far from national and regional capitals. Borderlands often show signs of peripherality such as economic stagnation, poor infrastructure, population decrease or low investments. Nevertheless, not all borderland areas can be considered as peripheral. Some of them disposing of a certain economic potential are suitable for collaboration and consequently for economic development.

Our approach is based on the empirical knowledge that the influence of the state frontier is usually most visible in the first municipality behind the border and in the first town behind the border that provides services at a higher level of hierarchy. As this study focuses mainly on the countryside, we have defined the South Moravian rural borderland according to the individual areas as follows:

Slovak borderland - the region of Horňácko: Hrubá Vrbka, Javorník, Kuželov, Malá Vrbka, Nová Lhota, Radějov, Tvarožná Lhota.

Slovak borderland - the region of Hodonín: Petrov, Sudoměřice, Rohatec, Mikulčice, Lužice, Josefov, Prušánky.

Slovak borderland - the region of Břeclav: Kostice, Lanžhot, Moravská Nová Ves, Týnec, Tvrdonice

Austrian borderland - the region of Mikulov: Březí, Dobré Pole, Hevlín, Hrabětice, Jevišovka, Novosedly, Nový Přerov, Sedlec, Šanov,

Austrian borderland - the region of Znojmo: Dyjákovice, Dyjákovičky, Hnanice, Hrádek, Chvalovice, Jaroslavice, Slup, Strachotice, Šatov,

Austrian borderland - the region of Vranov: Horní Břečkov, Lančov, Lukov, Podhradí nad Dyjí, Podmolí, Podmyče, Starý Petřín, Stálky, Šafov, Uherčice, Vranov nad Dyjí, Vratěnín.

In these parts of the analyses, where we found it purposeful, we monitored the regional differences according to the defined borderland areas. The analysis is based on "hard" statistical data analyses from different official sources. The strategic part was based also on the summary of existing strategic documents of individual LEADER+ Local Action Groups, namely their SWOT analyses from which proper SWOT analysis was compiled as a basis for defining a complex borderland strategy.

Hypothetically, it can be assumed that major differences will be recorded in several areas. The Slovak and Austrian borderlands will differ based on the historic development at the end of the first half of the past century. Other major differences will be undoubtedly conditioned by distance from the central towns of Hodonín, Břeclav and Znojmo and also by accessibility as the triangle of the Moravian- Austrian - Slovak borders is where important European routes between Hamburg - Bucharest and Warsaw - Vienna intersect. An important role may also be played by natural conditions for the development of primary and other activities (mineral resources in the region of Hodonín), transport micro-position, economic activity, attractiveness in terms of tourism, human factor, and individual differences. Some of the factors condition one another others do not. 


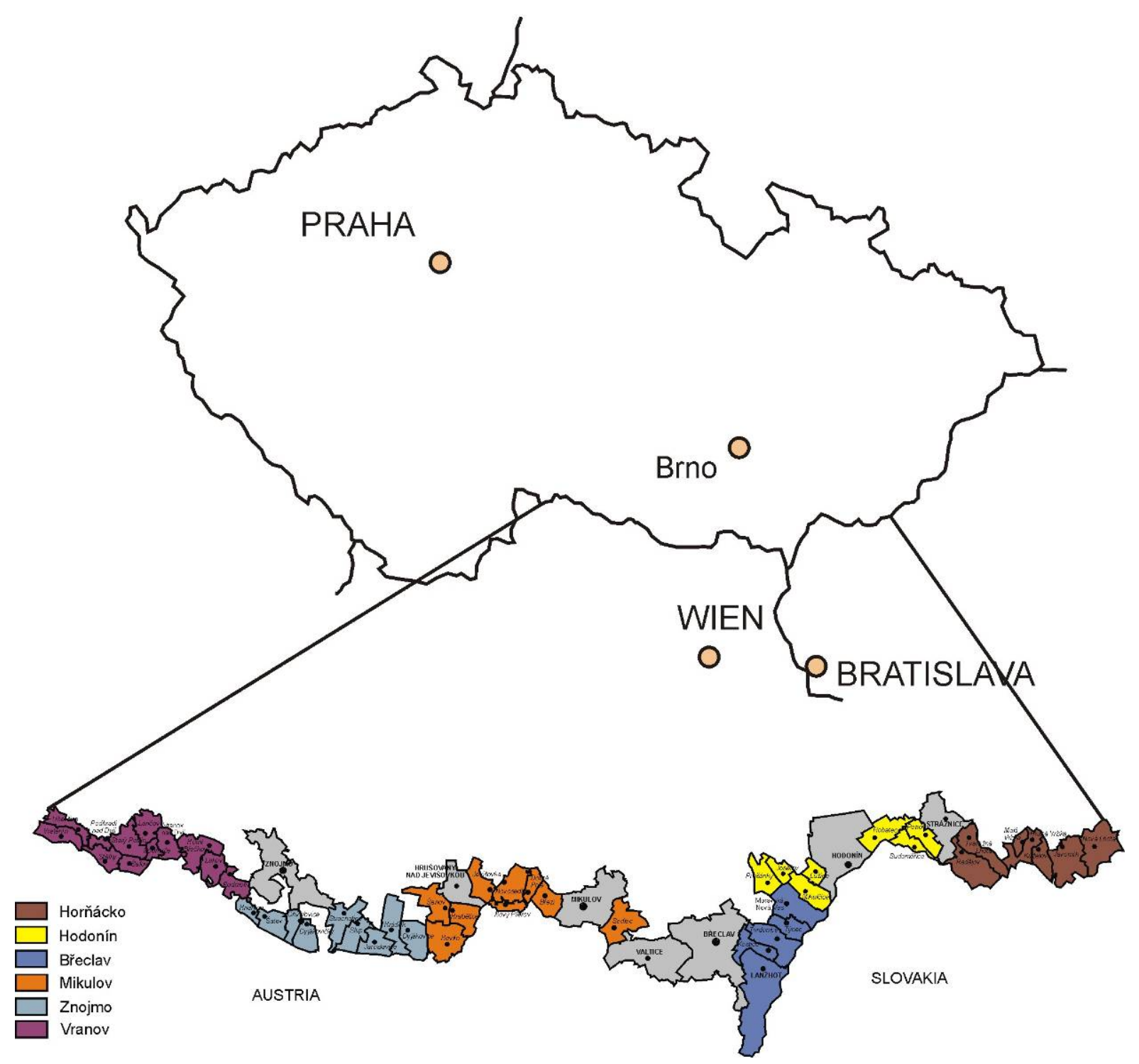

Fig 1. Individual parts of the territory under study. Drawing: J. Pokorná.

\section{Natural conditions of South Moravian borderland}

The South Moravian borderland is characterised by the transition from the fertile lowlands of the south and west, dominated by agricultural farmland, to the more mountainous country of the east, with larger stretches of meadows and forests. Nearly sixty percent of the territory is agricultural land, including 37,000 hectares of arable land, 4,800 hectares of permanent grassland, 2,500 hectares of vineyards and 1,300 hectares of gardens and orchards. Forests and woodlands cover 18,500 hectares, or $25 \%$ of the total land area, whilst almost 10,000 hectares $(1.3 \%)$ is built-up land. Most of the region is classified by the European Environment Agency as primarily a composite landscape, combining large areas of nonirrigated arable land, some broadleaved and coniferous forest, and built-up settlements, with a secondary landscape of broad-pattern intensive agriculture ${ }^{6}$. Water bodies occupy around $3.3 \%$ of the land area. The situation in individual parts of the borderland is different though (Table 1).

\footnotetext{
${ }^{6}$ European Environment Agency, CORINE database
} 


\begin{tabular}{|l|c|c|c|c|c|c|c|}
\hline $\begin{array}{l}\text { Part of the } \\
\text { borderland }\end{array}$ & $\begin{array}{l}\text { arable } \\
\text { land }\end{array}$ & vineyards & $\begin{array}{l}\text { gardens, } \\
\text { orchards }\end{array}$ & $\begin{array}{l}\text { permanent } \\
\text { grassland }\end{array}$ & forests & $\begin{array}{l}\text { water } \\
\text { bodies }\end{array}$ & $\begin{array}{l}\text { built-up } \\
\text { areas }\end{array}$ \\
\hline Horńácko & 27.8 & 0.0 & 1.1 & 24.2 & 41.8 & 0.7 & 0.9 \\
\hline Hodonín & 52.0 & 3.3 & 7.0 & 6.5 & 14.9 & 3.3 & 2.8 \\
\hline Břeclav & 39.4 & 2.2 & 1.7 & 5.6 & 38.6 & 5.3 & 1.4 \\
\hline Mikulov & 64.2 & 8.6 & 1.4 & 1.4 & 10.8 & 3.1 & 1.3 \\
\hline Znojmo & 71.7 & 6.0 & 1.8 & 0.9 & 7.6 & 3.5 & 1.2 \\
\hline Vranov & 46.7 & 0.1 & 0.7 & 3.5 & 33.5 & 3.6 & 1.1 \\
\hline
\end{tabular}

Tab 1. Land use structure in individual parts of the borderland 2010 [\%]. Source: Public Database. Czech Statistical Office Prague.

The borderland with Austria has larger proportions of arable land. In the borderland with Slovakia (except for the surroundings of Hodonín), arable land stands back to forests (in the case of Hornácko forests and grasslands of the White Carpathians, in the case of Břeclav the surroundings of floodplain forests on the confluence of the Morava and Dyje Rivers). Vineyards, gardens and orchards are concentrated in the centre of the borderland territory, whereas its western and eastern fringes have very few areas of this type. Permanent grasslands are concentrated almost only in the mountainous Hornácko region. Three of the borderland parts have insufficient forest areas, which is rather untypical for Czechia. The shares of built-up areas depend on the size of rural settlements (in relation to their cadastral areas) which are the largest in the surroundings of Hodonín.

The region is a typical agricultural landscape dominated by arable land that covers more than $50 \%$ of the total area. The second largest and stable area is represented by forests, which cover more than $25 \%$ of the total area. Permanent grassland recorded significant shrinkage. On the other hand, the development of settlements (i.e. built up area) is well apparent. An increase was noted for water surfaces (reestablishment of dried ponds or creation of new water bodies), other areas and recreational areas (this category started to occur since the 1950s). The most stable areas are those of arable land and large forest complexes in the east and floodplain forests in the south. Settlement cores remained stable, too. The most dynamic areas are floodplains of the Dyje River (Skokanová et al. 2009).

Significant areas of the South Moravian landscape are protected by national and international decrees reflecting their environmental importance. The Podyji National Park was established in 1991 covering $63 \mathrm{~km}^{2}$ of primeval forest in the Dyje River valley along the Austrian border. The corresponding Thayatal National Park was established on the Austrian side of the border in 2000. The Czech and Austrian authorities cooperate in the management and promotion of the area, signing an agreement on cross-border crossings by tourists hiking in the parks in 2006 and developing the Podyjí-Thayatal Visitor Centre through a partnership using INTERREG III funding $^{7}$. The Pavlovské vrchy limestone hills in the south of the region were decreed as a UNESCO Biosphere Reserve in 1986, and the reserve was extended in 2003 to include floodplain forests at the confluence of the Morava and Dyje Rivers and the landscape of the Lednice-Valtice area, forming the new Lower Morava Biosphere Reserve (Dolní Morava), encompassing 24,200 hectares between the Nové Mlýny reservoir and the Austrian and Slovak borders. The area of the Biosphere reserve includes a strictly protected 6,900 hectare core, 9,000 hectares of the buffer zone, and 8,834 hectares of the transition zone. Around 20,000 people live in the area, mainly in the transition zone ${ }^{8}$. As with all UNESCO Biosphere Reserves, the management plan includes objectives for both nature conservation and sustainable development, with a particular focus on sustainable tourism.

\footnotetext{
${ }^{7}$ Inforegio

${ }^{8}$ UNESCO
} 


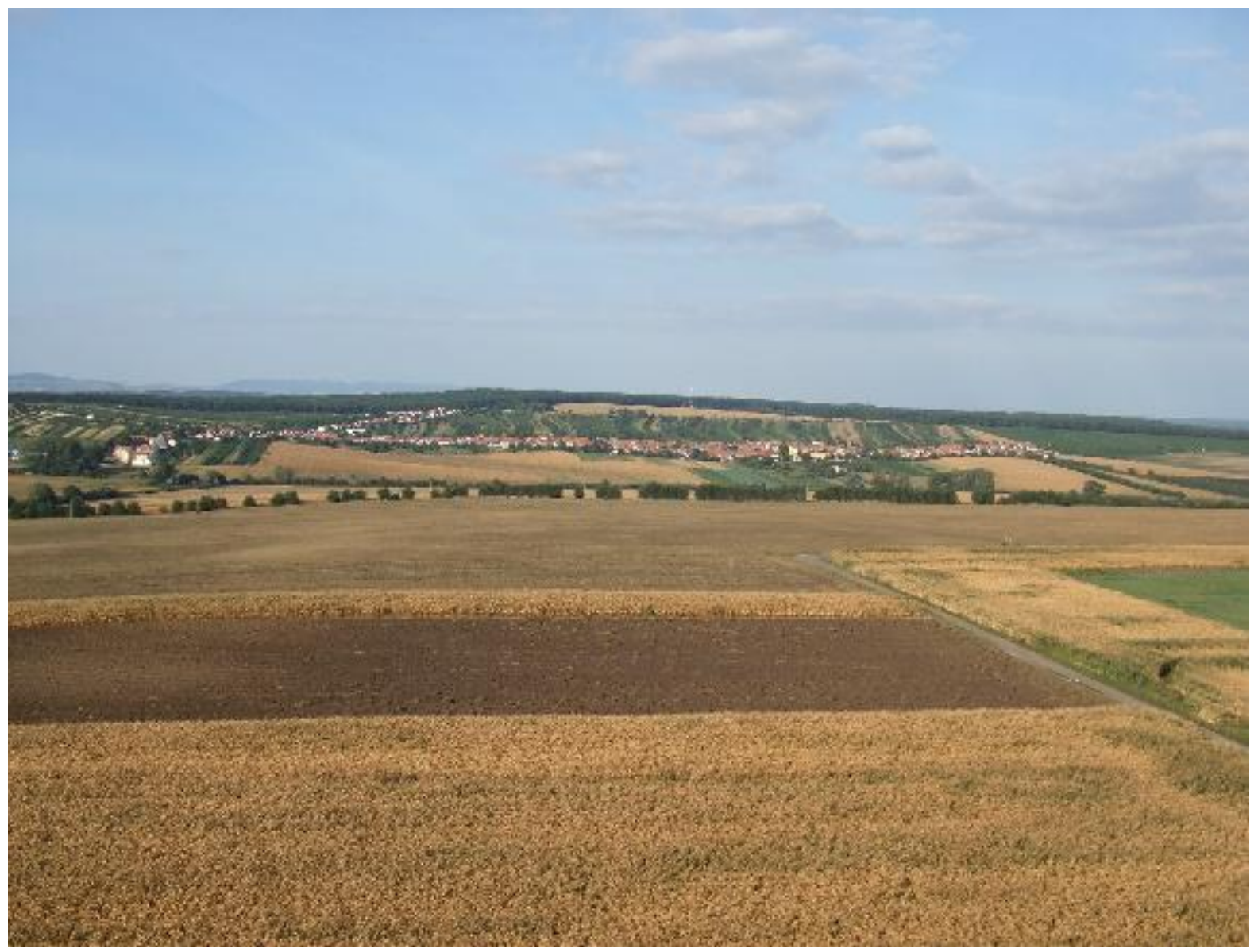

Fig 2. Landscape of the Moravian-Slovak borderland near the village of Sudoměrice. A view from Czechia to Slovakia. Photo K. Stonawská.

The Lower Morava R. Biosphere Reserve includes the Lednice-Valtice Cultural Landscape, which was separately recognised by UNESCO as a World Heritage Site in 1996 . The $283 \mathrm{~km}^{2}$ area protects the landscape fashioned by the Dukes of Liechtenstein in the $17^{\text {th }}$ to $19^{\text {th }}$ centuries, combining Baroque architecture, Neo-Gothic castles and countryside landscaping reflecting the European romantic tradition. The Lednice fishponds (decreed in 1990) and Lower Dyje floodplain (1993) are Ramsar sites. The Czech and South Moravia authorities have further decreed the Protected Landscape Areas of Pálava Hills and White Carpathians. The latter is also the UNESCO biosphere reserve. Additionally, there are many small-scale protected areas in the borderland and 5 bird reserves of the NATURA 2000.

\section{Settlement of the South Moravian borderland}

The central part of the South Moravian borderland can be considered as the area between Hodonín and Znojmo with important transit routes and the concentration of the largest towns and rural municipalities. Nevertheless, the peripheral character of the area is augmented by the fact that none of the Moravian middle-sized (Hodonín, Břeclav, Znojmo) nor small towns such as Strážnice or Mikulov have an equal partner on the other side of the border. Perhaps the only pair can be formed between Hodonín and a much smaller town of Holíc in Slovakia.

The development of the number of inhabitants in the individual parts of the South Moravian borderland reflects the history of relevant parts in the region. There is an obvious difference between the Moravian-Slovak and Moravian-Austrian parts. The most significant aspect is the population decrease in the Moravian-Austrian borderland as a result of the post-war ethnical exchange and the German war losses. Between the censuses made in 1930 and 1950, this part of the borderland lost at least one third of its population. The number of inhabitants in the Slovak borderland dropped only very slightly (it may be assumed that a part of the population settled on the border with Austria) or not at all. 
Until 1930, most of the borderland parts experienced a rising number of inhabitants with the exception of the westernmost area where there were periods of drops in the period from 1880 - 1910. After 1945, there was a general decrease in the number of inhabitants in the South Moravian rural borderland in all its areas, which lasted until 1991. In sporadic cases, different development was observed in some micro-regions and during certain intra-census periods. However; over the past decade of 2001 - 2011, the population growth was positive in the borderland areas.

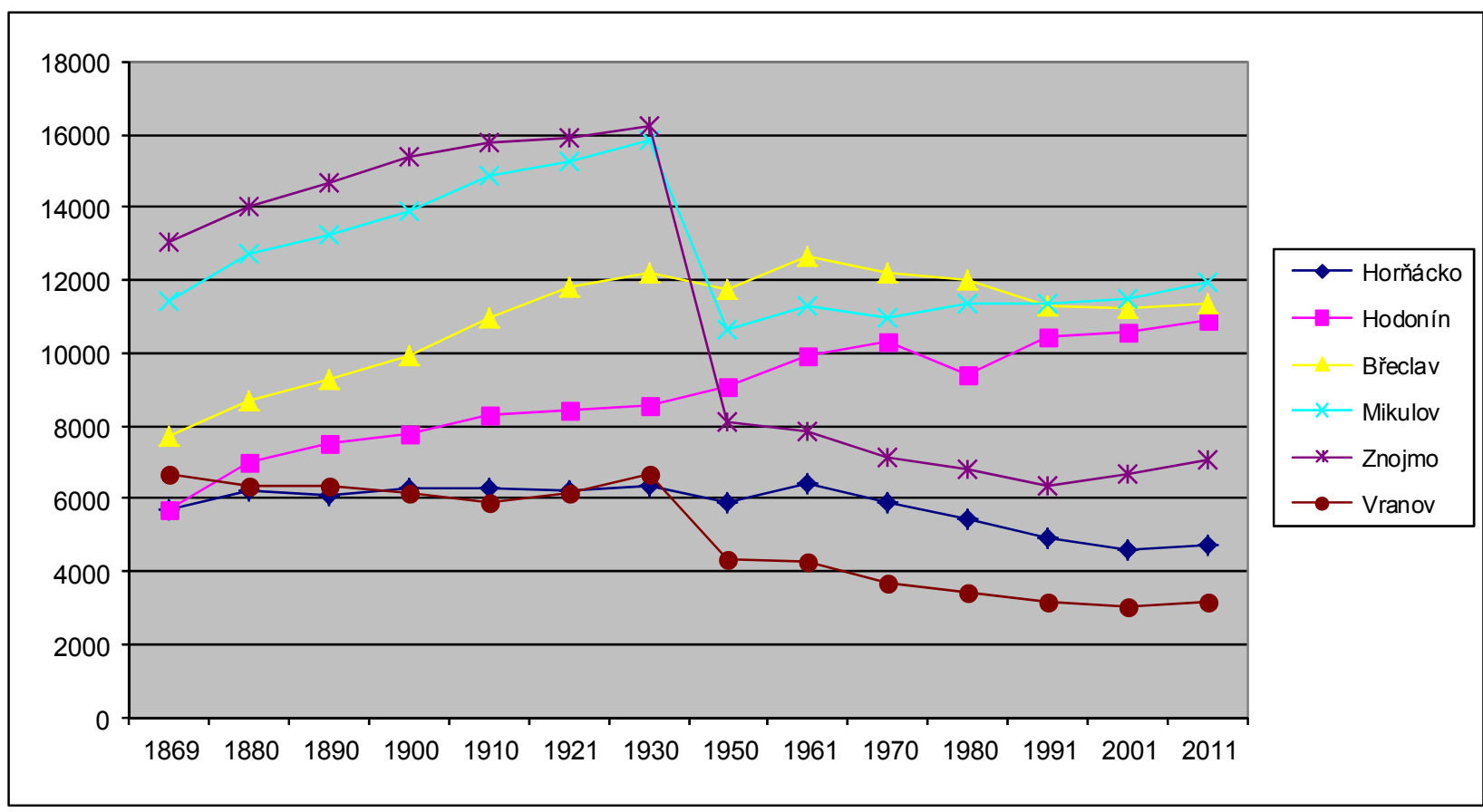

Fig 3. Development of the number of inhabitants in the individual parts of the South Moravian region between 1869 2001. Source: Růžková, J., Škrabal, J., eds. (2006): Historický lexikon obcí České republiky 1869 - 2005. Volume I., Prague, Czech Statistical Office, 760 p. Sčítání lidu 2011. Prague, Czech Statistical Office.

The latest population trends were monitored on the basis of the population balance over the five-year period of 2007 - 2011. Data provided for the individual parts of the borderland are shown in Table 2.

In terms of the natural population movement there are major differences between the areas of the Moravian - Slovak borders that are mostly losing and the Moravian - Austrian border that is gaining in population. This may be the outcome of the post-war ethnical exchange of the population which resulted in a young population base at the borders with Austria. As far as the mechanical population movement is concerned, all the considered parts gain in migration with the exception of the western part of the Moravian-Austrian border (region of Vranov), which is one of the most marginal part of the Czech borderland in general. The total population dynamics is negative in both these peripheral areas, i.e. the regions of Horñácko and Vranov, while the borderland population is increasing in the other areas. The population turnover rises from the east which is relatively stable against the mechanical population movement towards the west which is, on the contrary, considerably sensitive. Thus, in the South Moravian borderland there is generally no depopulation taking place while the migration has a positive balance in most of the areas.

The settlement structure of the South Moravian region is also differentiated. It is based upon three middle-sized towns of Hodonín, Breclav and Znojmo. Among them, the role of centres is played by the small towns of Strážnice, Mikulov and Hrušovany nad Jevišovkou. Velká nad Veličkou in the east and Vranov nad Dyji in the west cannot even be characterised as small towns. Besides the above-mentioned centres, there are other small towns located in the South Moravian borderland, which are of minimum central importance: Hrušovany nad Jevišovkou, Valtice and Lanžhot. 


\begin{tabular}{|l|r|r|r|r|r|}
\hline Area & \multicolumn{1}{|l|}{ New born } & \multicolumn{1}{l|}{ Dead } & \multicolumn{1}{l|}{ Immigrants } & \multicolumn{1}{l|}{ Emigrants } & \multicolumn{2}{l|}{$\begin{array}{l}\text { Average population } \\
\text { number }\end{array}$} \\
\hline Horňácko & 179 & 269 & 411 & 387 & 4402 \\
\hline Hodonín & 481 & 496 & 1259 & 990 & 10744 \\
\hline Břeclav & 515 & 579 & 1205 & 1010 & 11283 \\
\hline Mikulov & 478 & 393 & 1192 & 892 & 6525 \\
\hline Znojmo & 416 & 292 & 949 & 813 & 3208 \\
\hline Vranov & 157 & 160 & 418 & 462 & $\mathbf{4 5 0 9 2}$ \\
\hline Total & $\mathbf{2 2 2 6}$ & $\mathbf{2 1 8 9}$ & $\mathbf{5 4 3 4}$ & $\mathbf{4 5 5 4}$ & $\mathbf{4 5 3}$ \\
\hline
\end{tabular}

Tab 2. Population balance of individual parts of the South Moravian borderland in 2007 - 2011. Source: Database of demographic data of the CR municipalities. Prague, Czech Statistical Office.

The regions of Hodonín and Břeclav are characterised by large and very large compact rural municipalities. Towards the eastern and western borders, the large rural municipalities are replaced by middle-sized municipalities and in the west there are small and very small municipalities. In very rare cases, these municipalities have separate hamlets and if so, these can be found mainly in the western part of the South Moravian borderland.

As regards the population structure indicators, we chose the share of persons over 65 years of age (as indicator of ageing), the share of inhabitants over 15 years of age with tertiary education and the share of households with a PC connected to the Internet. All the data is comparable with 2011 and 2001. The results are compared with the national average (Table 3).

\begin{tabular}{|l|c|c|c|c|c|c|}
\hline \multirow{2}{*}{$\begin{array}{l}\text { Part of the } \\
\text { borderland }\end{array}$} & \multicolumn{2}{|c|}{ Inhabitants 65+ } & \multicolumn{2}{c|}{ Tertiary education } & \multicolumn{2}{c|}{ PC with Internet } \\
\cline { 2 - 7 } & $\mathbf{2 0 1 1}$ & $\mathbf{2 0 0 1}$ & $\mathbf{2 0 1 1}$ & $\mathbf{2 0 0 1}$ & $\mathbf{2 0 1 1}$ & $\mathbf{2 0 0 1}$ \\
\hline Horňácko & 16.8 & 16.7 & 6.3 & 3.2 & 49.2 & 2.2 \\
\hline Hodonín & 15.8 & 14.0 & 9.6 & 5.5 & 59.4 & 6.6 \\
\hline Břeclav & 16.0 & 14.7 & 7.8 & 4.7 & 57.1 & 4.4 \\
\hline Mikulov & 12.3 & 10.5 & 4.5 & 2.5 & 52.8 & 2.3 \\
\hline Znojmo & 12.2 & 11.4 & 4.2 & 2.5 & 52.8 & 2.3 \\
\hline Vranov & 14.1 & 13.4 & 6.2 & 3.7 & 45.2 & 3.5 \\
\hline In total & $\mathbf{1 4 . 6}$ & $\mathbf{1 3 . 4}$ & $\mathbf{6 . 8}$ & $\mathbf{3 . 9}$ & $\mathbf{5 4 . 1}$ & $\mathbf{4 . 0}$ \\
\hline $\begin{array}{l}\text { National } \\
\text { average }\end{array}$ & $\mathbf{1 5 . 9}$ & $\mathbf{1 3 . 8}$ & $\mathbf{1 2 . 4}$ & $\mathbf{8 . 9}$ & $\mathbf{5 6 . 6}$ & $\mathbf{6 . 4}$ \\
\hline
\end{tabular}

Tab 3. Comparison of several social indicators according to the 2001 and 2011 censuses [\%]. Source of basic data: Czech Statistical Office Prague, own research.

As far as demographic ageing is concerned, there are differences between the Slovak borderland with the older population and the Austrian borderland where, due to the post-war population exchange, the share of senior citizens is still substantially lower than the national average. Still, the region of Vranov, from where a large part of the young generation had moved out, has somewhat worse characteristics than the other two parts of the border with Austria. The region of Horňácko, as a traditional periphery, has maintained the oldest age structure since the 2001 census and the trend is likely to continue. In other parts of the borderland, the issue of ageing becomes more urgent.

Similar differences can be found in the share of population with the tertiary education, which is substantially lower in the Austrian part of the borderland than in the Slovak part. Nevertheless, in all parts of the borderland, the educational population age structure is significantly lower than the national average. The most favourable situation is seen in the micro-regions of district towns 
Hodonín and Břeclav, which consist of large rural settlements with partial effects of suburbanisation from these towns. Surprisingly, the highest share of university graduates in the Austrian borderland can be found in the region of Vranov. One can only guess whether these are well educated people who intentionally choose to live on the periphery in order to avoid the excessively commercialised towns. Between 2001 and 2011, the share of university graduates in the individual parts of the studied borderland increased by $2-4$ percentage points on average.

The share of households owning PCs connected to the Internet surprisingly approaches the national average and in two cases it even exceeds the average. This can be explained by the fact that the Internet connection is more needful on the periphery as it more often substitutes face-to-face contacts (this situation was similar during the 2001 census with the equipment of peripheries with passenger cars). The least PC-equipped regions are the two peripheral areas of the border regions of Horñácko and Vranov, where the share of households with the Internet is below 50\%, while back in 2001 it seemed that the region of Vranov (probably thanks to its vicinity to Austria) caught up on the arrival of these technologies better than some other comparable border areas.

\section{Economy of the South Moravian borderland}

The structure of economic activities in the South Moravian borderland is, to a certain extent, affected by natural conditions favouring agriculture. At the beginning of the 1990's, i.e. at the outset of the transformation of the Czech economy, the employment rate in the primary sector was very high in the South Moravian borderland both in the wider region and the rest of the country. The entire Austrian borderland was of agricultural character, while there was a certain east-western gradient with a maximum in the region of Vranov, where the primary sector was the leading employer (42\% of economically active population). During the transformation, there was a rapid drop in the employment rate. The number of employees decreased more at the Slovak border (the greatest drop by $2 / 3$ in the region of Horñácko), a milder decrease was experienced at the Austrian border (approximately $1 / 2$ ), where agriculture remains an important employer in the country with the share of approximately $20 \%$.

Historically, the secondary sector has developed more at the Slovak border, which also corresponds to the high employment rate in the sector with the maximum concentration in the region of Hodonín. The whole of the South Moravian rural borderland with the exception of Hodonín region (Moravian lignite mines in Mikulčice) and the eastern part of the Austrian borderland (sugar refinery in Hrušovany nad Jevišovkou, Praga plant in Novosedly, and brickworks in Hevlín and Novosedly) was not a centre of important industrial plants at the beginning of the 1990's and therefore the transformation of industrial production did not show too much there. Naturally, towns were important industrial hubs, including heavy industry plants where a part of the countryside population commuted to work. In less industrial parts, the number of people employed in the secondary sector stagnated or slightly increased whereas the Břeclav and Hodonín regions recorded a slight- and a steeper drop, respectively.

Other sectors of economic activities, in particular services, were undersized; they started gaining importance during the 1990's and now, with the exception of Horñácko, services, they are the leading employer in the whole borderland. Tourism has developed most dynamically as the whole region has very good tourist conditions with a number of natural, cultural, architectonic and technical landmarks (the Lednice-Valtice Cultural Landscape, the urban conservation area of Mikulov, Mikulčice museum exhibits, Bat'a's Canal) in the region or it in its immediate vicinity, combined with a long folklore and wine growing tradition and big water reservoirs of Nové Mlýny and Vranov. What is highly attractive is the Austrian borderland made accessible thanks to a fairly high number of border crossing points (except for the region of Vranov) and offering a comprehensive range of accommodation facilities. 


\begin{tabular}{|c|c|c|c|c|c|c|c|c|c|}
\hline \multirow[b]{2}{*}{ Sector } & \multicolumn{4}{|c|}{ Number of entities } & \multirow{2}{*}{$\begin{array}{c}\text { Number of } \\
\text { entities } \\
\text { per } 1,000 \\
\text { inhabitants }\end{array}$} & \multicolumn{4}{|c|}{$\begin{array}{l}\text { Number of entities with the } \\
\text { number of employees }\end{array}$} \\
\hline & Primary & Secondary & Other & Total & & 1- 9 & 10- 49 & 50- 249 & $\begin{array}{l}250 \\
\text { and } \\
\text { more }\end{array}$ \\
\hline Horňácko & 177 & 180 & 351 & 790 & 180 & 50 & 14 & 0 & 0 \\
\hline $\begin{array}{l}\text { Region of } \\
\text { Hodonín }\end{array}$ & 170 & 203 & 1334 & 2168 & 203 & 195 & 49 & 4 & 3 \\
\hline $\begin{array}{l}\text { Region of } \\
\text { Břeclav }\end{array}$ & 373 & 178 & 1088 & 2005 & 178 & 158 & 42 & 5 & 0 \\
\hline $\begin{array}{l}\text { Region of } \\
\text { Mikulov }\end{array}$ & 352 & 193 & 1116 & 2244 & 193 & 182 & 47 & 4 & 1 \\
\hline $\begin{array}{l}\text { Region of } \\
\text { Znojmo }\end{array}$ & 168 & 182 & 702 & 1253 & 182 & 88 & 44 & 9 & 0 \\
\hline $\begin{array}{l}\text { Region of } \\
\text { Vranov }\end{array}$ & 160 & 243 & 389 & 785 & 243 & 63 & 9 & 1 & 0 \\
\hline
\end{tabular}

Tab 4. Business activities in the South Moravian borderland as at $31^{\text {st }}$ December 2008. Source: Municipal and local statistics, Czech Statistical Office Prague, [http://vdb.czso.cz/xml/mos.html], downloaded on $2^{\text {nd }}$ March, Portal of the Regional Information Services, Centre for Regional Development of the CR, [http://www.risy.cz/index.php], (2 March 2010).

The scale of current business activities is demonstrated by the number of business entities per 1,000 inhabitants. With respect to this indicator, the region of Vranov stands out distinctly. However, looking closely, these are mostly natural persons not offering jobs and therefore their importance is quite low. This is rather the consequence of missing jobs for potential employees in this micro-region. The employer structure in the entire borderland rests on micro businesses (1 - 9 employees) and small-sized businesses (10 - 49 employees). The lowest number of employers is reported in peripheral parts of the borderland and the highest number is reported in the region of Hodonín, which is, along with the region of Břeclav, a part of one of the regional development axes in the whole Czech Republic. Given the size structure of the municipalities, more than a half of the economically active population is forced to commute to work beyond the borders of the municipality and the borderland thus functions as a base for adjacent larger centres.

Technical and social amenities in the area are considerably affected by the population size in the settlements, their position and importance within the settlement system. Most amenities are provided in the highly populated regions of Hodonín and Břeclav, which is strongly contrasted with the amenities in other parts of the borderland, particularly in the region of Horñácko, the central and western part of the Austrian borderland.

A high percentage of flats reaching almost the national average is connected to water supply mains. The number of flats connected to gas supply is also high compared to other borderlands; in the regions of Hodonín and Břeclav it is very high; the only exception is the region of Vranov with as little as $6.8 \%$ proportion of flats with gas supply. The connection rate to the public sewerage system is again the highest in the regions of Hodonín and Břeclav, and the lowest in the Austrian borderland, which is due to its strongly peripheral character.

All parts of the borderland offer primary education facilities. The only rural secondary school is located in Sedlec near Mikulov. However, the students can easily commute to municipal centres in the borderland. Health care is reduced to individual surgeries, specialised care is provided by towns in the borderland. Amenities for senior citizens are available in every part of the borderland with the exception of the regions of Hodonín and Horñácko. 


\begin{tabular}{|l|c|c|c|}
\hline Area & Connection to gas & Connection to water mains & Connection to public sewerage \\
\hline Horňácko & 62.4 & 94.0. & 44.5 \\
\hline Hodonín & 90.1 & 97.3 & 65.9 \\
\hline Břeclav & 91.1 & 93.8 & 63.9 \\
\hline Mikulov & 62.6 & 96.5 & 31.1 \\
\hline Znojmo & 67.6 & 93.5 & 26.6 \\
\hline Vranov & 6.8 & 94.4 & 27.0 \\
\hline
\end{tabular}

Tab 5. Technical facilities in the dwelling stock of the South Moravian rural borderland. Source: Population census, houses and flats, 2001. Czech Statistical Office Prague.

The unemployment rate in the South Moravian borderland is higher in both the regional and the national context. It shows a characteristic seasonal trend, which is due to the seasonal type of work in agriculture, construction and tourism. For a long time, the lowest unemployment rate has been reported in the region of Breclav and the highest in the west and in the centre with the highest seasonal unemployment rate fluctuations. It also seems that the last-mentioned two parts of the borderland are most sensitive to crises phenomena, which have occurred since 2008.

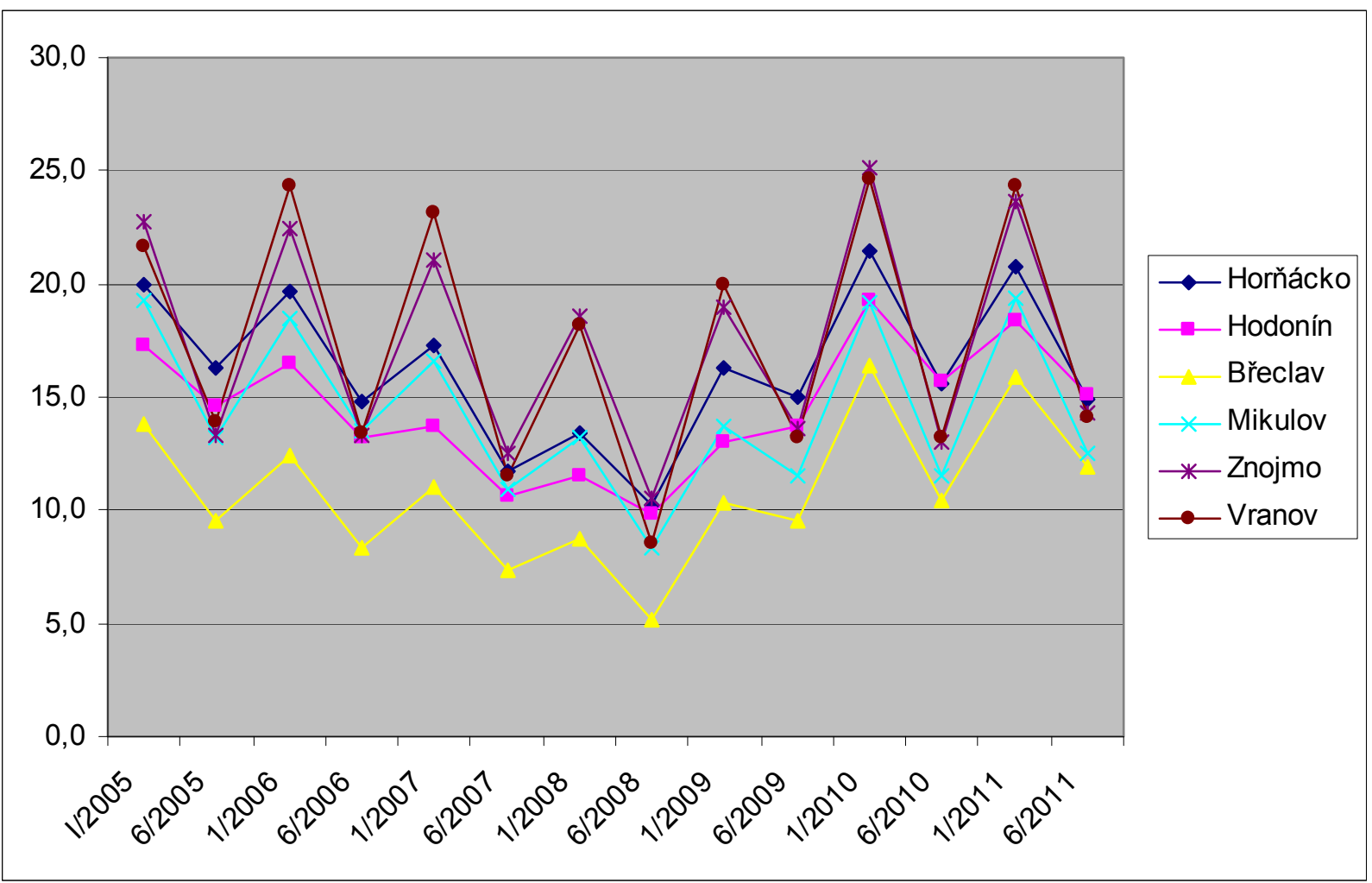

Fig 4. Unemployment rate development in the individual parts of the South Moravian borderland in 2005 - 2011. Source: Statistical data on unemployment in regions, Integrated portal of the Ministry of Labour and Social Affairs, [http://portal.mpsv.cz/sz/stat/nz/uzem], (2 March 2010).

\section{Potential strategies of the South Moravian borderland}

Since 1997, the South Moravian borderland has been associated in the trilateral Euro-region of Pomoraví / Záhorie / Weinviertel. The eastern part of the borderland is part of the White Carpathians / Biele Karpaty Euro-region. According to Holeček (2008), the Euro-regions do create an institutional framework for a potential cross-boundary cooperation, but they are not (at least on the Czech side) used enough directly by the border municipalities or their inhabitants and the interest of the borderland inhabitants in personal contacts with the partners on the other side is low. 
In determining potential strategies, we have stemmed out from the developed SWOT analyses made by existing local action groups within the LEADER+ programme. These analyses are a precondition for applying for financial aid and they should also serve as a research supporting groundwork to determine the integrated development strategies (Hanke, Psyk-Piotrowska, 2006). In this part of the borderland there are five local action groups. The local action group Jemnicko reaches this area only marginally in the west.

The following four strategies were taken as a basis for the strategic factor analysis: two at the Moravian - Slovak border (Local Action Groups Horňácko and Ostrožsko and LAG Strážnicko) and two at the Moravian - Austrian border (LAG Mikulovsko, o.p.s. and LAG Znojemské vinařství). Given the differing historic development (path dependency), these strategic factors of micro regions in the Slovak and Austrian regions that are related to the historic development of the state border character differ. Other factors related to natural conditions, geographical position, relation to Brno etc. may be applicable to both parts of the borderland.

\begin{tabular}{|l|l|r|r|r|r|}
\hline Name & Centre & Population & Size [km $\left.{ }^{2}\right]$ & Inhab./km² & Municipalities \\
\hline $\begin{array}{l}\text { LAG Horňácko a } \\
\text { Ostrožsko, o.s. }\end{array}$ & Uh. Ostroh & 26221 & 264.7 & 98 & 16 \\
\hline LAG Strážnicko & Strážnice & 16905 & 147.6 & 113 & 11 \\
\hline LAG Dolní Morava, o.s. & Lanžhot & 44198 & 341.9 & 128 & 21 \\
\hline LAG Mikulovsko, o.p.s & Mikulov & 20557 & 271.5 & 75 & 18 \\
\hline LAG Znojemské vinařství & Znojmo & 33698 & 497.5 & 66 & 41 \\
\hline
\end{tabular}

Tab 6. List of local action groups in the LEADER+ programme in the South Moravian borderland.

The main strengths of the South Moravian borderland are considered to be:

Existence of attractive natural and cultural localities including e.g. the Nové Mlýny water reservoirs and the Vranov reservoir, the Pálava limestone cliffs, the Lednice-Valtice Cultural Landscape, a number of castles, manor houses and valuable religious buildings and ruins, borderland strongholds encouraging historic military artefact tourism, pilgrimage points. Some of these sights are of supra-regional and international importance and create conditions for the development of tourism including its revival forms.

Network of relatively large rural municipalities (except for the westernmost part) offering sufficient local markets to maintain the basic commercial and social services and having sufficient local budgets to co-fund supporting programmes.

Excellent climate and soil conditions for agriculture make it possible to develop the market production of wine. Viticulture is linked with the surviving folklore and growing tourism.

Development of quaternary activities - Faculty of Horticulture, Mendel University in Lednice, spas in Hodonín, Lednice, Pasohlávky.

High quality environment, particularly in terms of air cleanliness (except of Hodonín microregion). However, the local pollution of surface water and groundwater plays a role. A part of the area enjoys a high degree of protection (the Podyji National Park, Pálava Hills and White Carpathians Landscape Protected Areas, Lower Morava River biosphere reserve ).

Important transit position connecting regional Czech and foreign centres. Transport vicinity of Vienna and Bratislava (this is mainly true with resects to the transit part of the borderland in the regions of Hodonín and Břeclav). The natural barrier of the state border is formed largely by watercourses (with the exception of the White Carpathians). 
However, there are also weaknesses there, which are as follows:

Intensification of tourism for regional development is hindered by its strongly seasonal nature restricted to summer months only, lack of high standard facilities, inadequate networks of additional leisure-time amenities, cultural and sports facilities, missing gastronomic facilities in a number of communes, insufficient destination management, marketing and promotion.

A significant problem is below-average education including the lack of technically qualified manpower. In relation to Austria, there is also a language barrier. Communes with people settling in later are affected by the lack of interest of their inhabitants in development, by general apathy and by the dilapidation of some premises.

What is important is the poor condition of secondary and local roads making the transit more difficult. A number of municipalities do not have wastewater treatment plants. In some parts of the borderland it is difficult to cross the border (no roads, national park).

Relatively intensive agriculture results in relatively high erosion levels, lower biodiversity of cultivated parts of the land, lack of scattered greenery and strong soil water deficit in the east.

The opportunities in the Czech - Austrian borderland include:

Cooperation of rural micro-regions, regions and international cooperation between Euroregions, use of regional support programmes, CR and EU.

Support of non-production forms of agriculture including the recovery of the irrigation system, introduction of power generation from renewable resources and organic farming drawing upon the Austrian experience.

Demand for relevant components of tourism including its booming forms. An opportunity for building infrastructure for tourism, biking including the supporting infrastructure, renewal of trails and tracks connecting both sides of the border.

Support of small and medium-sized businesses engaged in local tourism, construction and services. Development of services for senior citizens and tourist services. Support of lifelong learning and emphasis on the role of schools for the community.

The main threats in the Czech - Austrian borderland are as follows:

Reduced internal potential of the region resulting from the departure of educated and young people outside the borderland. Disappearance of village schools and their functions due to the decreasing number of pupils, reduced quality of schooling. Growing share of socially marginalised groups of people. Decline of culture, sports, health care. Missing motivation.

Lack of water and moisture, periodic flooding. Devastation of the landscape by intensive agriculture or, potentially, by the closedown of agricultural operations. Lack of discipline in waste management. Long-term contradictions between land protection and use.

Economy stagnation. Reduced competitiveness compared to other areas. Increasing share of individual transport at the expense of public transport.

The threats are conditioned by objective factors: natural conditions, settlement structure and remoteness from important centres. Therefore, the exclusion of most of them is problematic without a long-term systematic and economically sustainable support.

In the next step we have combined the specific internal and external key factors into strategic possibilities. In theory, the following strategies can be defined:

a. So strategy: intensifying the strengths by making use of opportunities.

b. ST strategy: using strengths to eliminate threats.

c. WO strategy: minimising weaknesses by employing opportunities.

d. WT strategy: minimising weaknesses by excluding threats. 
In reality, the corresponding strategies may be joined and combined to arrive at two principal alternative approaches, with the first strategy focusing more on the economic development and with the second strategy underscoring the improved quality of life. In practice, these strategies will most likely overlap and complement each other with respect to the interests and preferences of local inhabitants.

Strategy 1. To develop productive agriculture including the growing of wine, fruits, vegetables and other crops, possibly related with the comprehensive development of tourism based on architectonic, natural, historic, gastronomic and folklore attractions using the existing demand, support, international (in particular, Austrian) experience and international cooperation. To keep younger and more educated people in this part of the borderland by developing multifaceted economic activities with a larger share of tertiary functions and by highlighting the spa function. The seasonal character of the activities should be mitigated by their diversification. To develop a corresponding image of the region.

Strategy 2. To focus attention on the improvement of life quality for local inhabitants and by doing so to keep younger and more educated people in the region. To focus on the development of services for the inhabitants (including services for senior citizens) and on the construction and maintenance of the technical infrastructure. To encourage the community life, develop a positive relationship of the inhabitants to their region and to form identity (particularly in those areas where the population was exchanged after 1945). To attract amenity migrants.

\section{Discussion and conclusion}

Is the South-Moravian rural borderland peripheral? Let us check the four-dimensional concept of Ferrão and Lopes. Empirical research suggests that two of the six sections of the borderland under investigation are extremely remote: the Vranov micro-region in the west and Horñácko in the east of the area. On the other side, central micro-regions are relatively well accessible by both individual and public transport. The level of dependency, based on the core - periphery model (Krugman 2011), is also different. It can be stated that micro-regions in the hinterland of district towns Znojmo, Břeclav and Hodonín are less dependent as compared with Mikulov and especially with Vranov and Horňácko.

The focus on the periphery as a difference relates to the global-local interplay (Woods 2007). The difference in this sense is seen in keeping regional and local identity and tradition. We can suggest that the main variance can be found between micro-regions in the Slovak part of the borderland with strong tradition and relatively stable population and those in the Austrian borderland where the population was exchanged after World War II.

Periphery as a discourse is connected with the representational approach reflecting the specific (positive) character of peripheral places. This can be seen among other things in the historical and natural heritage. The situation seems to be contradictory in comparison with the abovementioned aspects. Only the most remote parts of the South-Moravian borderland have available the cultural and natural heritage. However, the central section is rich in protected areas and historical seats, too.

To conclude this part of the discussion, it seems to be clear that the South-Moravian rural borderland is different with the highest level of peripherality exhibited by the most western and most eastern sections. The remaining micro-regions show more limited signs of peripherality.

Despite certain strengths, the South Moravian borderland is and will probably remain a peripheral area in the future. The purpose of its strategic plan probably cannot focus on changing the fact. The future must be seen in the answer to the question of whether the South Moravian rural borderland is sustainable. The question is what can be understood by rural region sustainability. Marsden (2003) poses the question as an alternative to the traditional agro-industrial model as well as a post-production model and links it to the environmentally more conscious behaviour of producers and consumers along with the government control. However, this is sustainability in the ecological sense of the word. Bowler et al. (2002) perceive rural sustainability as a social construction. Van Berkel and Verburg (2011) recognise 
approximately four possible factors of development (sustainability) of the countryside: production agriculture, non-production agriculture, rural tourism and conservation (of the nature and landscape).

Our discussions are based upon three equal sustainability pillars - economic, social and environmental (Bassiago, 1999). However, there is no absolute agreement on this issue amongst the authors. Occasionally, one of the pillars is replaced in relation to the nature of the object, the sustainability of which is analysed. For example, Mirshojaeian and Kaneko (2001) speak about institutional, economic and environmental pillars compared to the sustainability at the level of the states. Hawkes (2001) mentions a fourth pillar - cultural. In our view, it is about the sustainability of the rural landscape, sustainability of rural settlements and sustainability of their inhabitants.

The sustainability of the rural landscape (Kizos et al. 2010) is about maintaining its characteristic features including biodiversity, esthetical values, image and historic heritage, and identity. Blacksell (2010) speaks about changes brought about by the shift from the productive agricultural use of the land towards a multifunctional cultivation lately exercised in the postsocialist countries, but not only there (Pérez, 2010). The risks this poses include, on the one hand, the transformation into an urbanised, i.e. technogenic country with a rising share of transport, industrial and residential areas and technical infrastructure sites and, on the other hand, devastation as a result of erosion, terminated cultivation etc. Drought can become one more serious environmental risk. The contemporary development of the South-Moravian countryside was described by Vaishar at al. (2011). The authors found out that the rural landscape of the borderland is less impacted by contemporary changes as compared with less favourable areas in the north of the region or with suburban zones of Brno.

The sustainability of rural settlements consists in preserving their rural physical structure and in preserving their rural functions. On the one hand, the rural settlements are exposed to the urbanised trend pressures and on the other hand they are transformed along with the diminishing importance of the primary industrial sectors affecting the employment structure, gross domestic product and increasing importance of other functions. What is crucial is the preservation of social and commercial services at the basic hierarchical level. This may result in the development of residential and infrastructural zones that strongly restrict environmental stability, biodiversity, and landscape permeability. There is no doubt that the territory shows decreasing production. Here it should be pointed out that the decrease of jobs in the industrial sector has affected the rural borderland more seriously than the decrease of jobs in the primary sector. On the other hand, the peripheral position protects the borderland settlements from intensive changes of rural to urban character. There are some evidences of changes from agricultural to recreation function expressed as a relatively high share of summer cottages in suitable localities.

The sustainability of inhabitants consists primarily in the prevention of irreversible de-population tendencies (namely emigration and ageing), and secondarily in maintaining the relatively favourable demographic, social and educational structure to guarantee population reproduction also in the future. This may not necessarily concern depopulation only, but also cultural marginalisation (Bryant et al., 2011). Although de-population is not currently typical of the Czech countryside as a whole, it is becoming a serious issue in a number of countries (e.g. Bell et al. 2009, Pantyley, 2009). On the other hand, even in peripheral regions there are rural settlements with major population migration increments. Solana-Solana (2010) calls this phenomenon "rural gentrification". Jančák et al. (2010) draw attention to major differences in the quality of social capital between the permanently populated periphery and the border periphery where the population was ethically replaced after World War II. This also concerns the Czech-Austrian part of the South Moravian borderland contrary to the Czech-Slovak borderland. The results of our analysis show that only one micro-region (Vranovsko) is stressed by both natural and migration population decrease at the moment. 


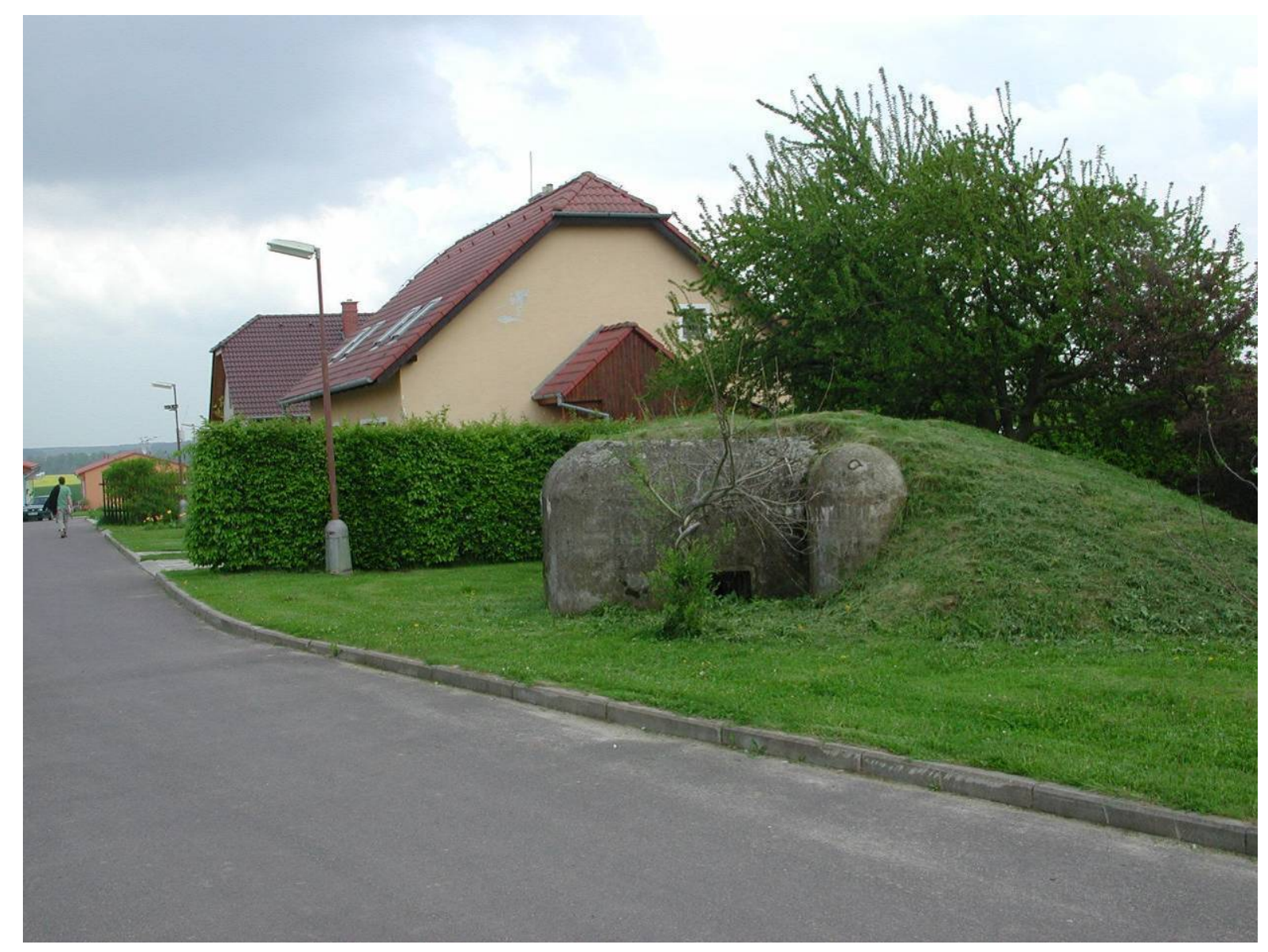

Fig 5. New detached houses in the border village Vratěnín. A bunker from the WWII period in the foreground right. Photo A. Vaishar.

It seems that the peripheral nature of the borderland can eliminate some of the aforesaid risks to a certain extent. These remote borderland micro-regions are not so much exposed to the strong urbanising and economic pressures changing the landscape and the settlement character. The remoteness may have adverse effects on the characteristics of the social system. The general problems of the peripheral regions are accompanied by specific characteristics of the region. The positive features include the positive image and surviving folklore, the negatives ones include the risk of drought. Nevertheless, the hypothesis about the South Moravian rural borderland being differentiated has been confirmed. This is evidenced also by the fact that Perlín et al. (2010) classified individual South-Moravian border microregions to different types within the typology of the Czech countryside.

If the landscape, settlements and population of the South Moravian borderland is preserved, a positive future of this region may be predicted, although at a lower level of development compared to the central parts of the region. Such regions give people a choice. It shows that the hustle and bustle of the central region can be changed for a tranquil environment of the periphery that can still address the basic needs of the inhabitants. We can agree with Schmied (2005) that the fact that some rural areas find it easier to adapt to the process of restructuring depends mainly, but not exclusively, on their natural, human and cultural resources, their socio-economic structure and their location.

\section{Acknowledgments}

The study was conducted as part of the grant project under the $7^{\text {th }} \mathrm{EU}$ Framework Programme no. SSH-CT-2008-225204 „Development of Europe's Rural Regions in the Era of Globalization", grant project of the National Research Programme II of the Ministry of Education, Youth and Sports of the Czech Republic, no. 2D06001 „Development interests of the borderland regions", grant project of the Internal Grant Agency of the Faculty of Agronomy, Mendel 
University in Brno, no. TP4/2011 "Current Development of the South Moravian countryside“. The work was presented at the workshop funded by the Visegrad Fund in October 2012.

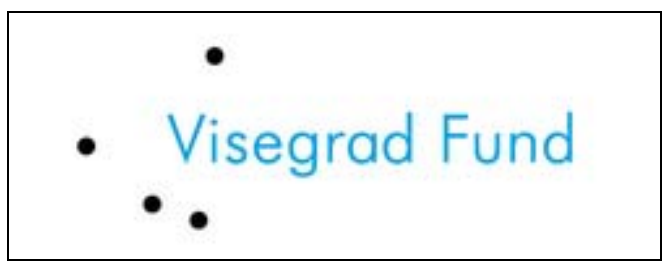

References

[1] Bański, J., Dobrowolski, J., Flaga, M., Janicki, W. \& Wesołowska, M. (2010). Wplyw granicy państwowej na kierunki rozwoju społeczno-gospodarczego wschodnej części wojewódzstwa Lubelskiego. Warszawa: Instytut geografii i przestrzennego zagospodarowania PAN.

[2] Bassiago, A. D. (1999): Economic, social, and environmental sustainability in development theory and urban planning practice. Environmentalist 19(2), 145-161.

[3] Bell, S., Montarzino, A., Aspinall, P., Peneze, Z. \& Nicodemus, O. (2009): Rural society, social inclusion and landscape change in Central and Eastern Europe: A case study of Latvia. Sociologia Ruralis 49(3), 295-326. Doi 10.1111/j.1467-9523.2009.00480.x.

[4] Berkel, D. B. van \& Verburg, P. H. (2011): Sensitising rural policy: Assessing spatial variation in rural development options for Europe. Land Use Policy 28(3), 447-459. Doi: 10.1016/j.landusepol.2010.09.002.

[5] Blacksell, M. (2010): Agriculture and landscape in the $21^{\text {st }}$ century Europe: the postcommunist transition. European Countryside 2(1), 13-24. Doi 10.2478/v10091-010-0002-8.

[6] Bowler, I. R., Bryant, C. R. \& Cocklin, C. (2002): The sustainability of rural systems. Dordrecht: Kluwer.

[7] Bryant, R. L., Paniagua, A. \& Kizos, T. (2011): Conceptualising 'shadow landscape' in political ecology and rural studies. Land Use Policy 28(3), 460-471. Doi: 10.1016/j.landusepol.2010.09.005.

[8] Bufon, M. (2007): Border regions in a re-integrated Europe. Moravian Geographical Reports 15(1), 2-13.

[9] Chromý, P. (2000): Historickogeografické aspekty vymezování pohraničí jako součást geografické analýzy. Geografie 105(1), 63-76.

[10] Ferrão, J. \& Lopes, R. (2004): Understanding peripheral rural areas as contexts for economic development (pp. 31-61). In Labrianidis, L., ed., The future of rural peripheries. Aldershot: Ashgate.

[11] Häkli J. \& Kaplan, D. H. (2002): Learning from Europe? Borderlands in social and geographical context (pp. 1-17). In Häkli J. \& Kaplan, D. H., eds., Boundaries and Place. Lanham: Rowman \& Littlefield.

[12] Hampl, M. (2000): Pohraniční regiony České republiky: Současné tendence rozvojové diferenciace. Geografie 105(3), 241-254.

[13] Hanke, K. \& Psyk-Piotrowska, E. (2006): SWOT analysis of the LEADER+ pilot programmes implementation - on the basis of research conducted in two communes. Wies i Rolnictwo Nr. 133, 77-89.

[14] Hawkes, J. (2001): The fourth pillar of sustainability: culture's essential role in public planning. Melbourne: Common Grand Publishing. 
[15] Holeček, P. (2008): Euroregiony na území České republiky, Rakouska a Slovinska a jejich prínos pro rozvoj pohraničí. [Diploma thesis]. Olomouc: Palacký University.

[16] Jančák, V., Chromý, P., Marada, M., Havlíček, T. \& Vondráčková, P. (2010): Social capital as a factor in the development of peripheral areas: an analysis of selected components of social capital in Czechia's typologically different peripheries. Geografie 115(2), 207-222.

[17] Jeřábek, M., Dokoupil, J. \& Havlíček, T., eds. (2004): České pohraniči: Bariéra nebo prostor zprostredkování? Prague: Academia.

[18] Kizos, T., Primdahl, J., Kristensen, L. S. \& Busck, A. G. (2010): Introduction: Landscape change and rural development. Landscape Research 35(6), 571-576. Doi: 10.1080/01426397.2010.502749.

[19] Krugman, P. (2011): The new economic geography, now middle-aged. Regional Studies 45(1), 1-7. Doi: 10.1080/00343404.2011.537127.

[20] Marsden, T. (2003): The condition of rural sustainability. Assen: van Gorcum.

[21] Mirshojaeian, H. \& Kaneko, S. (2011): Dynamic sustainability assessment of countries at the macro level: A principal component analysis. Ecological Indicators 11(3), 811-823. Doi: 10.1016/j.ecolind.2010.10.007.

[22] Pantyley, V. (2009): Demographic Situation of Rural Population in Ukraine in the Period of Intensive Socio-Economic Transformation. European Countryside 1(1), 34-52. Doi: 10.2478/v10091-009-0004-6.

[23] Pérez, R. S. (2010): Multifuncionalidad agraria y territorio. Algunas reflexiones y propuestas de análisis. Eure 36(109), 5-33.

[24] Perlín, R., Kučerová, S. \& Kučera, Z. (2010): Typologie venkovského prostoru Česka. Geografie 115(2), 161-187.

[25] Schmied, D. (2002): Winning and Losing, The changing geography of Europe's rural areas. Aldershot: Ashgate.

[26] Skokanová, H., Stránská, T., Havlíček, M., Borovec, R., Eremiášová, Rysková, R. \& Svoboda, J. (2009): Land use changes of the South Moravia, Czech Republic, from 1836 to 2006. Geophysical Research Abstracts vol. 11, p. 2093.

[27] Solana-Solana, M. (2010): Rural gentrification in Catalonia, Spain: A case study of migration, social change and conflicts in the Empordanet area. Geoforum 41(3), 508-517. Doi: 10.1016/j.geoforum.2010.01.005.

[28] Vaishar, A., Zapletalová, J. \& Dvořák, P. (2008): Border administrative units in the Czech Republic. Moravian Geographical Reports 16(1), 46-54.

[29] Vaishar, A., Jakešová, L. \& Náplavová, M. (2011): Current problems of South-Moravian rural landscape. European Countryside 3(4), 265-281. Doi: 10.2478/v10091-012-0008-5.

[30] Woods, M. (2007): Engaging the global countryside: globalization, hybridity, and the reconstruction of rural place. Progress in Human Geography 31(4), 485-507. Doi: $10.1177 / 0309132507079503$.

[31] Woods, M. \& Jones, L. (2009): Contextual report on Jihomoravský kraj case study area [research report]. Aberystwyth: University of Wales. 